\title{
The Political Development of Women in Albania
}

\author{
By Eglantina Farruku
}

\begin{abstract}
The issue of women's representation and participation in politics and decision-making is not anymore an unknown or un-discussed issue in Albanian. This paper attempts to investigate the conceptual and material bases of women's participation in the politics in Albania. It will be bringing facts and arguments regarding the participation of women not only in political life and decision making but also is going to investigate in detail in membership of political parties. Further investigation will be on how much weight women have on media coverage of different aspects of their life.

Politic cannot be done properly, if the vision and the concepts of the woman's in general would not be brought up by their women representatives in the political arena. Despite the increase number of women in parliament, many advocate that the women until now had been only a decoration on the back ground of the political life and these needed to be changed. It seems that this change now taking place in Albania that would take some time.

The study tries to provide information and analyses on this regard. Then the paper reaches a conclusion that there is still a long way to go in Albania for convincing more women to participate in politics, because without of them the politic would not be addressing whole problems of the country.
\end{abstract}

Key words Politic, Women, Participation, Parliament, Parties, Election

\section{Introduction}

In Albania, there are an increase number of women in parliament. There are women who are minister and also have got important roles in government. Further, there is opposition political voice of woman as a sign that women are part of the politics, policy making and decision taking organs but still there is more to be done. Life is composed by two gender and we need to let them take their role without putting obstacles in their political, economical and social carrier, but giving them a chance to prove that even them are equal with the man with the opportunities, thoughts and ideas that they can bring in social life of a country.

This part of the study is divided into three sections in order to review the sources. The first section focuses Women and Political Life, second section includes Women and Political Parties and the third section includes Woman and Media.

\section{Research Method}

This study includes qualitative research methodology, by emphasizing words and uses some data that were collected from different sources. There are many different sources where we can find information about Political Participation of Woman in Albania, but it is obvious that these are investigation different perspective of women and there are different interpretations which are good. This study uses Albania Legislation,

${ }^{1}$ Non Conventional Energy Resources Investigation Institute (INENCO) of National University of Salta (UNSa) and National Council of Scientific and Technical Research (CONICET), Av. Bolivia 5150, A4400FVY, Salta, Argentina. Phone: +54 93874255424. 
Codes, Reports, the results of elections as primary sources. Then books, articles and other information which are internet are treated as secondary sources.

\section{Literature Review}

There are literatures on the topic which investigate political participation of women in Albania. Some of them highlight lack of participation of the women and some other try to prove that politics is men job rather than women. However the Albanian government currently has 7 woman ministers out of 21 ministers (Prime-Ministery Page), while it has 24 women deputies/ 140 deputies (Century Newspaper, 2013). If we compare with Ukraine for example, there are only 2 women in the Cabinet of Ministers despite the fact that in the present Parliament of Ukraine, women make up only $11.1 \%$ of its membership out of 450 deputies (Wikipedia, 2015). So, if we compare Ukraine with Albania, we can say that Albania gives more presence than representation in government, but its representation is lower than Ukraine's. Therefore, concerning political participation, the important aspect of the participation is representation rather than presence. In another point of view it is hard for a woman in Albania to get actively involved in politics. Even though there are positive models of women from all political parties, most of them have to put up with a harsh political environment. Male domination of parliament and of politics renders political language rude and violent, a difficult model to accept from women.

\section{Women Involved in Political Life and Decision-Making Process}

Similarly to the rest of the world, women in Albania make up more than half of the population (Hazizaj, On Situation of Women And Girls In The Republic of Albania, 2006, p. 10). However, their role in political participation remains insignificant, when referring to women's political participation in the parliament, central and local government or political parties. Women' Participation in political life still faces many challenges and obstacles which are male domination, the structure of political parties as well as the culture of formal political structures that ignore women's attempts to be part of political life.

Table1: Percentage of woman elected deputies during main elections (Central Electoral Commission)

\begin{tabular}{|l|l|l|}
\hline & Seats Available & Woman $\%$ \\
\hline 1991 Election & 140 & 28.8 \\
\hline 1997 Election & 140 & 12.1 \\
\hline 2001 Election & 140 & 5.2 \\
\hline 2005 Election & 140 & 7 \\
\hline 2009 Election & 140 & 16.4 \\
\hline 2013 Election & 140 & 17.8 \\
\hline
\end{tabular}


Table 1 shows numbers of member of the Parliament and how much women of these members, as percentages. In the Chart, it shows that number of women representative in the parliament is higher than the current parliament. At that time, $28.8 \%$ of the parliament was women. While in the last election in 2013 , there are $17.8 \%$ of them women.

At table 2 there is information about political participation of the women during 20052011 who were candidates at the general and local elections. The table aims to show how many candidates of women were elected as result of it. It is important to note that number of candidates of women is much higher in the local election then the general election. Based on this information we see that the number of elected women has increased in the general elections, but it is low in the local election or inexistent. Hence, it seems that there are various reasons why this imbalance has occurred. One of them may be the lack of women's interest in politics. For example, in the 2007 local elections, only 33 of the 1,073 candidates nominated for mayoral posts were women (OSCE/ODIHR, 2007, p. 15). Also the existence of the male-dominated model results in women either rejecting politics altogether or rejecting male-style politics (Bari, 2005, p. 34).

It is assumed that women would not have enough time to deal with governmental issues. Then if women spend time on politics and governmental issue, they have to compromise their responsibilities (traditionally women should care of children and family) that cause extra obstacles for them in everyday life. But this does not mean that these women are weak, inferior, isolated or independent, it is just a matter of choice. They can share the time between the family and political life because women's participation in politics emphasizes the quality of life and reflects the priorities of families, and ethnic and racial minorities.

Table 2: Political Participation of Women during the years 2005-2011 (Central Electoral Commission)

\begin{tabular}{|l|l|l|l|l|}
\hline & Candidates & Woman Candidates & Winner & Woman winner \\
\hline & & & & \\
2005 General Election & 1235 & 98 & 140 & 10 \\
\hline 2007 Local Election & 1073 & 33 & 374 & 9 \\
\hline 2009 General Election & 1143 & 356 & 140 & 23 \\
\hline 2011 Local Election & 1073 & 40 & 374 & 2 \\
\hline
\end{tabular}

Actions to be taken by Governments commit themselves to establishing the goal of gender balance in governmental bodies and committees, public administrative entities, judiciary, protect and promote the equal rights of women and men to engage in political activities. But still women's participation in decision-making processes remains at a low level and this is conditioned by the qualities of the democratic development of the society; from the economic, social and cultural development of the country; by heritage and existing mentalities and by the features of the transition period in Albania. In this point of view the situation is not relevant to their lack of interest to be involved in politics; neither is it an indication of women's inabilities in this regard. It concerns the difficulties that women are faced with in adjusting themselves to the current reality 
surrounding Albanian politics.

In 2007, The National Strategy on Gender Equity and Domestic Violence, an important milestone was the implementation of a strategy to increase women's participation in decision-making in a more direct way, by setting quotas for the participation of women in the lists of Parliament, a measure that brought the immediate doubling of the number of women in the Albanian Parliament. Woman's participation in decision-making is a strategic goal for participation in political life; firstly, it is classified that less than $30 \%$ reveal higher inequality and are less inclusive and less democratic than others; secondly it is common knowledge that women uphold interests that are different from those to which men attach importance. Also women's active participation in politics brings new values into political life, with new forms of how to address the needs of society being introduced. It causes an increase in solidarity and equality, and helps construct a more democratic and more peaceful society.

\subsection{The 2005 elections}

The 2005 elections showed the realization of the political forces goal about the importance of women's participation in politics and in leadership. For the first time in the parliamentary history of Albania, a woman is elected for the position of the Speaker of the Parliament. Another positive thing was the signing of the "Code of Behaviour" by political forces on 27 May 2005, an initiative of the President of the Republic of Albania, that shows a de jure approval of these political forces to support and promote women candidates. Another point of view proves that Elections in 2005 marked the lowest level of women's participation in the political events of the country. Although there were a high number of women candidates for representatives, only 10 of them were elected. According to inter parliamentary union, this puts Albania in the last place in Europe and in the $114^{\text {th }}$ place in the world for the number of women as members of parliament.

Table 3: Results of Parliament Elections 2005 (ASET, 2009, p. 10)

\begin{tabular}{|c|c|c|c|c|c|c|}
\hline \multirow[b]{4}{*}{ Candidates } & \multirow[b]{3}{*}{$\begin{array}{l}\text { Political } \\
\text { Subjects }\end{array}$} & \multirow[b]{3}{*}{$\begin{array}{l}\text { Total } \\
\text { Candidates }\end{array}$} & \multicolumn{4}{|c|}{ From whom } \\
\hline & & & \multicolumn{2}{|c|}{ Female } & \multicolumn{2}{|c|}{ Independent candidates } \\
\hline & & & Total & $\%$ & Total & Female \\
\hline & 28 & 1235 & 98 & 7.9 & 12 & 2 \\
\hline Winner & 3 & 100 & 7 & 7 & 1 & 0 \\
\hline
\end{tabular}

Table 4: Composition of Parliament, July 2005 (ASET, 2009, p. 34)

\begin{tabular}{|l|l|l|}
\hline & Male & Female \\
\hline Speaker of Parliament & 0 & 1 \\
\hline Vice speaker of Parliament & 2 & 0 \\
\hline Heads of Parliamentary & 7 & 1 \\
\hline Representatives & 140 & 10 \\
\hline Heads of Parliamentary & 9 & 0 \\
\hline
\end{tabular}


Table 5: Participation of Women in the Government, July 2005 (INSTAT, 2007, p. 35)

\begin{tabular}{|l|l|l|}
\hline & Male & Female \\
\hline Prime Minister & 1 & 0 \\
\hline Vice Prime Minister & 1 & 0 \\
\hline Ministers & 17 & 1 \\
\hline Vice Ministers & 23 & 6 \\
\hline General Secretary & 15 & 2 \\
\hline
\end{tabular}

In 2005 three main civil organizations initiated the creation of the Coalition for encouragement of women, youth and minorities' participation of in politics. In the beginning

of February 2006, the coalition publicly declared an open petition, where a minimum quota of $30 \%$ participation of women was required in parliament and in the local and central government. The petition was openly supported by women groups of political parties in Albania, NGO's of women and by the ombudsperson. After the declaration of the petition about the quota, a number of political parties established a quota for women's participation as part of their status and political programs. In the beginning of September 2006, the Coalition had officially submitted to the Parliamentary Commission of Elective Reform its proposals for modifications of the Election Code (Hazizaj, On Situation of Women And Girls In The Republic of Albania, 2006, p. 10).

\subsection{The General Elections in 2009}

The 2009 elections were the first to take place after the adoption of a quota for women's participation in political life, and after the revisions to the Electoral Code approved in late 2008. Such result comes in addition to the approval of the Law No. 9970, dated July 24th, 2008 "On Gender Equity In the Society" dated December 19th, 2007. The law and the subsequent Electoral Code both stated that at least 30 percent of appointed positions should be filled by the under-represented sex (i.e. Women) and 30 percent of all candidates put forward in national and local elections should be from the underrepresented sex. While the mentioned law called for women's political participation to reach the level of $30 \%$ the Electoral Code did not put in place mechanisms that would guarantee that. In fact, by specifying that parties could fulfil the quota by either listing a woman in one of the first three names and/or as $30 \%$ of the whole list, many would argue that it created the conditions for a $30 \%$ target not to be met. The Electoral Code gave parties the latitude to decide whether they

would include women's names as one of three names at the top of the list or whether they would simply include women as $30 \%$ of the overall candidate list (ASET, 2009, p. $8)$. Twenty-three women deputies were elected in the parliamentary election of 28 June 2009 , which is $16.4 \%$ of the total (140) mandates. In the 2005 legislature, there had been ten women deputies (seven of them elected directly from multi-nominal lists), or $7 \%$ of the seats in parliament (ACER and ASET, 2009, p. 10). 
Table 6: Results of Parliament Elections 2009 (ACER and ASET, 2009, p. 11)

\begin{tabular}{|c|c|c|c|c|c|c|}
\hline \multirow[b]{4}{*}{ Candidates } & \multirow[b]{3}{*}{$\begin{array}{l}\text { Political } \\
\text { Subjects }\end{array}$} & \multirow[b]{3}{*}{$\begin{array}{l}\text { Total } \\
\text { Candidates }\end{array}$} & \multicolumn{4}{|c|}{ From whom } \\
\hline & & & \multicolumn{2}{|c|}{ Female } & \multicolumn{2}{|c|}{ Independent candidates } \\
\hline & & & Total & $\%$ & Total & Female \\
\hline & 9 & 1,143 & 356 & 31 & 12 & 2 \\
\hline Winner & 6 & 140 & 23 & 16.4 & 1 & 0 \\
\hline
\end{tabular}

The number of mandates held by women in the new parliament is a significant increase over previous elections, but the number would have been significantly higher if all political parties had included women as every third name, alternating from the top of the list all the way down, rather than putting a few taken women near the top and then filling in up to $30 \%$ of their lists from the bottom. But neither the Code nor the law on gender equality required parties to put women in winnable positions (ACER and ASET, 2009, p. 10).

\section{Women and Political Parties}

According to the current situation in Albania there is a perception that there is still a preference for males as political leaders. It is difficult for a woman in Albania to participate actively in politics because most of the young women face a harsh political surrounding. Actually, women's participation in political parties has increased and this is not due to the goodwill of party leaders but due to the reinforcement of the electoral code. However, there is still a long way to go and comply with the code.

Party organizations are mostly dominated by men and they are mostly using women as decorations during elections and afterwards there aren't many activities organized for them. However, within political parties women tend to be overrepresented in the supporting roles and underrepresented in positions of power with less networks of influence. Moreover, it is clear that women's efforts to be part of political parties are constrained by many factors as by the patriarchal system (politics more for man), family engagement, corruption and party interior nomination system. Also political language is mapping a very difficult model many women could not fit in.

It is observed that political parties activate women's forums especially before electoral campaigns. From here we see that there isn't any serious and complete involvement of women in politics by the political parties but they only do this to increase the number of votes, which seems to be a short-term solution, not a long-lasting and permanent one.

Women representatives in main parties are not a strong voice to impose their ideas over the party leadership yet and they need to be organized beyond the party limits in order to produce a much quieter and all-inclusive political environment towards problem-solving solutions. 
Table 7: Percentage of women on political parties' candidate lists during the 2009 general election (ACER and ASET, 2009, p. 16).

\begin{tabular}{|c|c|c|c|c|c|c|c|}
\hline 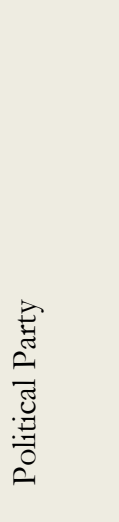 & 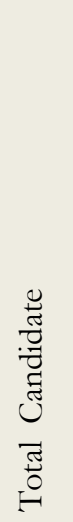 & 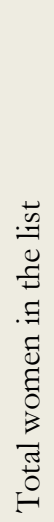 & $\begin{array}{l}\tilde{D} \\
\text { E్ } \\
0 \\
3 \\
0^{\circ}\end{array}$ & 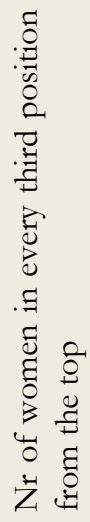 & 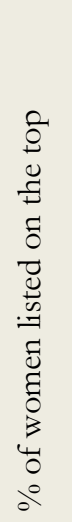 & 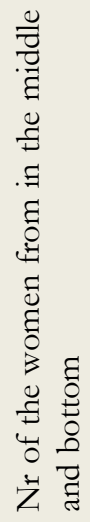 & 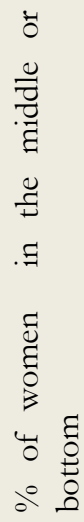 \\
\hline PD & 140 & 41 & 29.3 & 8 & 5.7 & 33 & 23.5 \\
\hline PS & 140 & 39 & 28 & 9 & 6.4 & 30 & 21.4 \\
\hline LSI & 140 & 43 & 30.7 & 7 & 5 & 36 & 25.7 \\
\hline PR & 140 & 41 & 29.3 & 7 & 5 & 34 & 24.3 \\
\hline PBDNJ & 101 & 37 & 36.6 & 8 & 7.9 & 29 & 28.7 \\
\hline PDK & 140 & 43 & 30.7 & 12 & 8.6 & 31 & 22.1 \\
\hline PSD & 117 & 29 & 24.8 & 12 & 10.3 & 17 & 14.5 \\
\hline PDI & 85 & 29 & 34.1 & 10 & 11.8 & 19 & 22.4 \\
\hline G99 & 140 & 54 & 38.6 & 9 & 6.4 & 45 & 32.1 \\
\hline
\end{tabular}

Based on the list of candidates nominee during the 2009 general election given above, it can be observed that even after the implementation of the $30 \%$ quota for the women in order to increase their participation, the results still show that the quota wasn't reached because their names were not placed in favourable positions to win.

There are several ways that parties can involve women. Establishing quotas in party organs is not enough, but a real implementation of the party in all forums would help although it might not guarantee a full and equal representation. Imposing more restriction on the gender party might affect the right to choose or to be chosen by narrowing the freedom of choice on the candidates.

Women in Albania are not as active as men in the economic life, so they have no much resource to support their electoral campaign. In this aspect, the parties need to allocate interior funds to sponsor their activities, to train develop their skills on the election campaign issues and support their cause. Another way that parties can promote their involvement is to give them access in the networks in order to empower women's wings and to establish the parity in the leadership and high executive committees. 


\section{Media and Its Role}

Media has an important role in promoting different issues and aspects of the social life in general and women's role and contribution in the political life in particular. Nowadays there is a need to promote the important role women play in politics, highlighting the potential they have as an added value in the so-called men's political stage.

Most of the TV programmes are designed to meet women's expectations or are womencentred programmes hosting women. If we look at these programmes carefully, we will notice that the woman's role in society is most likely consumed as the case of women's rights violation, which many non-governmental organizations are protesting against and proclaiming to be wrong. Also, there are programmes where the characters, the hard jobs and the difficult aspects of a woman's life are brought to light on every programme, showing the importance they have in the political, economic and social life in Albania. But if one measures the level and the influence of all of these programmes, they will see that they are not at the level women want to reach in reality. The coverage of the programmes on women's problems has to be increased, the subjects and the topics have to be more related to the positivity that they can bring with their nature, their way of thinking, and their way of solving different issues rose among them. Media needs to bring to the attention of public opinion the fact that despite the promises made during political electoral campaigns stated by the major party leaders, the number of women in politics is still very low to have the proper balance that they normally share with men in family and society. Women bring competition and that's one of the reasons that media ownership dominated by men might not allow it to happen.

The Albanian media continues to be commercial and politicized. Being under the influence of politics, it focuses on large-scale programmes involving heated political debates, where the dominant actors are men and some are woman. In this context, media needs to become an agent of change through its approach to women-related issues and direct the public in the belief that the society becomes stronger with women's participation.

As a society we need to stop women's discrimination which comes from our culture's mentality, and lack of information and education, and this can be done besides many other ways, through media as well. All the organizations that aim to protect and emancipate women must use all the media means and sources in order to achieve their goals. This will without doubt encourage women to have more confidence in themselves, to raise awareness on women's participation and to oppose with force or anything possible the harmful discrimination that affects their interests.

\section{Conclusion}

In order to increase women's participation in parliament, the executive branch, the local government and other institutions must have an influence on changing the social mindset without prejudice, with the right ideas on freedom, equality and living in harmony. Women have gained formal power but have not achieved parity with men in party leaderships. 
As long as the region's income gaps widen, many women will lack basic capabilities and remain excluded from eligibility pools for leadership. As long as millions of citizens are struggling to meet their basic needs, there will be limited political space to build coalitions around a women's rights agenda. And as long as state institutions suffer from problems of corruption, inefficiency and mismanagement, it will be difficult to achieve the desired outcomes only through law reinforcement but with political will from the party leaders and leadership.

Even if there is a reinforcement to have a higher participation of women in politics by establishing quotas for them, there still isn't much support from the parties, because even if they want to meet this criterion, they do not put them in favourable positions on the lists. Gender equality should be also part of the party constitution with provisions aiming at the enhancement of women's political participation.

The role of the media in shaping opinions in elections is immense. According to respondents, the TV and Radio media have provided the biggest coverage of women candidates in past elections and other aspects of life, but the coverage according to respondents remains insufficient to make the difference in paradigms and to change the attitudes and perception on them.

Women have the right stuff to be political leaders. When it comes to honesty and intelligence they highly value in leaders. Women need to be present and use their authority, values and skills because they know women's problems in society better than men.

\section{References}

ACER and ASET. (2009). Albania's 2009 Parliamentary Election:Monitoring the Implementation of Gender Quota and Women's Participation. Albanian Center for Economic Research and the Albanian Socio-Economic Think-Tank .

Albanian Center for Economic Research. (2011). The Situation of Women Leaders at the Local Level in Albania. A Baseline Analysis, Tirana.

Albanian women make their voices heard in national elections. (2009, August Saturday). Retrieved May Sunday, 2015, from United Nations Albania: http://www.un.org.al/subindex.php?faqe $=$ news\&newsid $=217$

Ara, M. R. (2006). Women, Partcipation and Empowerment in Local Goverment.

ASET, A. a. (2009). Monitoring the Implementation of Gender Quota and Women's Participation. Tirana: ACER and ASET.

Bari, F. (2005, November Thursday). Women's Political Participation: Issues and Challenges. Bangkok, Thailand: United Nations. Retrieved May Monday, 2015, from http://www.un.org/womenwatch/daw/egm/enabling-environment2005/docs/EGM-WPD-EE2005-EP.12\%20\%20draft $\% 20$ F.pdf

Central Electoral Commission. (n.d.). Retrieved May Saturday, 2015, from http://www2.cec.org.al/sq-al/

Century Newspaper. (2013, June Sunday). Retrieved April Monday, 2015, from Century Newspaper: http://www.shekulli.com.al/p.php?id=26139

Edler, A. (2012, November Tuesday). Retrieved April Saturday, 2015, from Policy.Mic: http://www.mic.com/articles/19350/hillary-clinton-replacement-why-susan-rice-should-takeover-the-state-department

Fourth World Conference on Women.Beijing Declaration. (n.d.). Retrieved May Sunday, 2015, from http://www.un.org/womenwatch/daw/beijing/platform/declar.htm

Fund, W. (2011). Women's Participation in Politics and Decision-Making in Ukraine. Ukrainian Women's Fund, Kiev.

Hammer, R. O. (1996-97). Men and Women Differ in Political Values:Theory and Implications. 
Hazizaj, A. (2006). On Situation of Women And Girls In The Republic of Albania. Albanian Coalition for Preparation of ALTERNATIVE Reports. Tirana: CEDAW.

Hazizaj, A. (2006). On Situation of Women and Girls in the Republic of Albania. CEDAW. Tirana: CEDAW.

INSTAT. (2007). Women and Men in Albania. INSTAT.

Kristin Jacoba Van der Leest, R. X. (2012). Gender Equality and Local Governance. Tirana.

Ministry of Labour, S. A. (n.d.). National Strategy on Gender Equality and Domestic Violence. 149. (OSCE, Trans.)

Ministry of Labour, S. A. (2007-2010). National Strategy on Gender:Equality and Domestic Violence. 149. (OSCE, Trans.) Tirana, Albania: Ministry of Labour, Social Affairs and Equal Opportunities .

Miranda, R. L. (2005). Impact of women's participation and leadership on outcomes. United Nations, Department of Economic and Social Affairs, Tirana.

O.Hammer, R. (1996-1997). Men and Women Differ in Political Values:Theory and Implications. (Formulations).

OSCE and ODIHR. (2009). Parliamentary Elections, 28 June 2009. OSCE and ODIHR, Tirana.

The Electoral Code of The Republic of Albania. (2012). 169. (OSCE, Trans.) Tirana.

OSCE/ODIHR. (2007). Election Observation Mission Report. OSCE/ODIHR, Warsaw.

Pascaud-Bécane, G. (1999). Participation of Women in Political Life. Inter-Parliamentary Union. Geneva: InterParliamentary Union.

Prime-Ministery Page. (n.d.). Retrieved April 25, 2015, from Prime Ministery: http://www.kryeministria.al/

Shvedova, N. (2002). Obstacles to Women's Participation in Parliament. Stockholm, Sweden: International IDEA.

Wikipedia. (2015, May Sunday). Retrieved May Sunday, 2015, from Verkhovna Rada: http://en.wikipedia.org/wiki/Verkhovna_Rada 